\title{
PERSEPSI PENYULUH TERHADAP STRATEGI KOMUNIKASI DALAM PEMANFATAN MEDIA INFORMASI DI ERA DIGITAL DI KABUPATEN TASIKMALAYA
}

\section{PERCEPTION OF EXTENSION WORKER ON COMMUNICATION STRATEGIES IN THE UTILIZATION OF INFORMATION MEDIA IN THE DIGITAL ERA IN TASIKMALAYA REGENCY}

\author{
Dona Setia Umbara**1, Lies Sulistoyowati ${ }^{2}$, Trisna Insan Noor ${ }^{2}$, Iwan Setiawan ${ }^{2}$ \\ ${ }^{1}$ Universitas Perjuangan Tasikmalaya \\ ${ }^{2}$ Universitas Padjadjaran, Bandung \\ *Email: donasetia@unper.ac.id \\ (Diterima 08-06-2021; Disetujui 05-07-2021)
}

\begin{abstract}
ABSTRAK
Pesatnya perkembangan teknologi digital banyak media yang dapat digunakan sehingga telah membawa berbagai perubahan baik pada diri penyuluh maupun petani. Media digital berupa media komunikasi yang bisa digunakan saat ini adalah media dunia maya atau media internet. Penyuluh pertanian memiliki peran penting dalam penyampain informasi serta dituntut mampu dalam menggunakan media internet dalam menunjang tugas pokok dan fungsinya sebagai penyuluh peratnian. Dalam melakukan aktivitas komunikasi dalam difusi inovasi. Tujuan penelitian ini mendeskripsikan persepsi penyuluh dalam pemanfaatan teknologi digital dalam penyampaian penyuluhan. Penelitian menggunakan metode survey dengan teknik penarikan sampel menggunakan sample random sampling yang terdiri atas 60 orang penyuluh. Anlisis data untuk mengukur persepsi penyuluh terhadap strategi komunikasi penyuluh dalam pemanfaatan media digital dilakukan dengan perhitungan skor. Hasil penelitian menunjukkan bahwa startegi komunikasi yang digunakan penyuluh dalam penyampaian penyuluhan kepada petani dapat diterapkan sehingga petani dapat melakukan kegiatan komunikasi secara inten menggunakan media digital lebih efisien dan efektif dalam penyampaian rekomendasi yang disarankan dalam usahtani. Penyuluh memiliki persepsi positif terhadap strategi komunikasi dalam pemanfaatan informasi yang dilihat dari teknik komunikasi, saluran komunikasi, pesan komunikasi dan penggunaan internet. Kegiatan penyuluhan dapat disampaikan kapan dan di mana saja, pemanfaatan teknologi informasi, dapat menggunakan sumber yang telah ada di internet untuk kemudian dibuat materi penyuluhan, dapat berhubungan secara real time menggunakan video conference atau video streaming, mempunyai kemampuan untuk mengintegrasikan bermacam unsur media teks, grafik, audio, dan video dalam pemberian penyuluhan kepada petani.
\end{abstract}

Kata kunci: digital, informasi, komunikasi, persepsi, strategi

\section{ABTRACT}

The rapid development of digital technology has many media that can be used so that it has brought various changes to both extension workers and farmers. Digital media in the form of communication media that can be used today are virtual world media or internet media. Agricultural instructors have an important role in conveying information and are required to be able to use internet media to support their main tasks and functions as agricultural extension workers. In carrying out communication activities in the diffusion of innovation. The purpose of this study is to describe the perception of extension workers in the use of digital technology in the delivery of counseling. The study used a survey method with a sampling technique using random sampling consisting of 60 extension workers. Data analysis to measure the instructor's perception of the instructor's communication strategy in the use of digital media was done by calculating the score. The results showed that the communication strategy used by extension workers in delivering 
counseling to farmers could be applied so that farmers could carry out intensive communication activities using digital media more efficiently and effectively in delivering recommendations suggested in farming. Extension workers have a positive perception of communication strategies in utilizing information as seen from communication techniques, communication channels, communication messages and internet usage. Extension activities can be delivered anytime and anywhere, use information technology, can use existing sources on the internet to then make extension materials, can connect in real time using video conference or video streaming, have the ability to integrate various elements of text media, graphics, audio, and video in providing counseling to farmers.

Keywords: digital, information, communication, perception, strategy

\section{PENDAHULUAN}

Indonesia merupakan negara agraris dimana sebagian besar masyarakatnya bekerja pada sektor pertanian. Selama ini, pemerintah sudah banyak membuat program pembangunan untuk kemajuan masyarakat khususnya bidang pertanian. Program-program tersebut sudah didiseminasikan ke masyarakat di seluruh nusantara yang dianggap cocok untuk dilaksanakan. Berbagai program pemerintah diupayakan dalam mewujudkan ketahanan pangan, menurut Dewan Ketahanan Pangan (2006) bahwa ketahanan pangan akan terwujud apabila tersedianya pangan yang cukup dan dapat diakses.

Untuk mewujudkan ketahanan pangan tersebut, maka pentingnya peran penyuluh dalam meningkatkan kapasitas petani agar petani terus konsisten meningkatkan produksi padinya. Dimana kita ketahui bahwa beras merupakan pangan pokok bangsa Indonesia sehingga harus selalu dijaga ketersediaannya dalam mewujudkan lumbung pangan keluarga maupun nasional. Prinsip penyuluhan pertanian adalah mengkomunikasikan secara baik, benar dan efektif. Berkatnya dalam dunia penyuluhan harus memiliki kemampuan berkomunikasi yang baik. Informasi dapat menjadi petunjuk apakah suatu informasi yang disampaikan secara jelas dan tepat sehingga informasi dapat mudah dipahami.

Kegiatan penyuluhan pertanian harus efektif mampu menyelenggarakan penyuluhan dengan metode yang sesuai dengan sasaran, waktu, tempat, obyek (materi) dan subyek (peserta). Materi yang disampaikan sesuai kebutuhan informasi, hal ini diperlukan komunikasi awal sebelum melaksanakan penyuluhan. Dukungan media penyuluhan seperti poster, video termasuk menggunakan media sosial elektronik yang dapat 
mendukung menyampaikan informasi dengan cepat.

Akses informasi pada media sosial di era modern seperti sekarang lebih beragam dan bervariasi. Internet dapat diakses oleh segala lapisan masyarakat, terbuka luas untuk mendapatkan berbagai informasi. Teknologi digital yang terus berkembang, memberikan peluang seluas-luasnya bagi kita untuk dapat memanfaatkan baik mendapatkan informasi maupun menyebarluaskan informasi secara cepat dalam ruang tanpa batas. Fasilitas ini dapat dimanfaatkan bagi penyuluh dalam menjalankan peran dan fungsi penyuluh untuk menjadi media belajar dan membantu memecahkan permasalahan. Sebagai penyuluh yang bertugas di BPP dituntut untuk selalu berupaya meningkatkan kapasitas guna menghadapi perkembangan teknologi yang demikian pesat.

Tantangan bagi penyuluh di era digital ini adalah kemampuan mengimbangi perkembangan teknologi, yang mengalami perubahan dalam jangka waktu yang relatif singkat. Sebagai penyuluh harus banyak membaca dan mempelajari perubahan-perubahan yang terjadi. Perubahan biasanya menjadi penyebab munculnya permasalahan baru, karena keberadaan sistem informasi yang tidak lagi dibatasi oleh ruang dan waktu, dapat menyebabkan terjadinya dampak yang tidak diharapkan. Sebagai penyuluh pertanian yang mengemban tugas mendiseminasikan teknologi bidang pertanian, menyampaikan informasiinformasi baru kepada petani. Kreatifitas diperlukan guna menghadapi permasalahan yang belum ada solusinya berdasarkan hasil penelitian dan pengkajian. Tentu perlu didukung oleh pengetahuan penyuluh, pengalaman di lapangan, tingkat pendidikan, kerja keras dan disiplin.

Peran penyuluh pertanian sebagai komunikator pertanian tercermin dari kemampuannya dalam menyampaikan dan mensosialisasikan program-program pembangunan pertanian, inovasi dan informasi pertanian terkini kepada petani dan dapat diterapkan oleh petani, mampu memberikan solusi atas permasalahan petani, membantu percepatan arus informasi dan membantu petani dalam proses pengambilan keputusan dalam berusahatani sehingga dapat mendorong petani untuk lebih maju, memperluas wawasan dan berorientasi pasar. Kondisi ini menuntut penyuluh pertanian untuk selalu meningkatkan kemampuannya melalui penguasaan informasi dan 
inovasi pertanian terkini. Pesatnya perkembangan teknologi informasi dan komunikasi (TIK) dewasa ini dapat dimanfaatkan oleh penyuluh pertanian untuk memperoleh beragai macam informasi secara mudah melalui berbagai media komunikasi baik media offline maupun media online (Asdar $d k k, 2018$ ).

Pemanfaatan informasi di era digital dapat diakses oleh siapa saja, tidak terkecuali penyuluh. Penyuluh selalu membutuhkan inovasi dari berbagai instansi dimana salah satu media yang dapat diakses saat ini adalah internet melalui cyber extension. Menurut Sumardjo dkk (2010) bahwa penyuluh sering dihadapkan pada kesenjangan inovasi pada saat berperan sebagai pendamping petani dalam membantu pemecahan permasalahan. Aplikasi teknologi informasi melalui sarana komputer maupun telepon seluler (handphone-hp) dalam implementasi cyber ekstension di beberapa negara dapat berfungsi untuk memepercepat proses pembelajaran masyarakat.

Pemanfaatan media di era digital ini dapat dijadikan sebagai strategi komunikasi. Dimana penyuluh telah mencoba menyusun pesan komunikasinya sebagai materi dengan berbagai media baik secara tradisional maupun modern. Oleh karena itu, perubahan media yang digunakan merupakan strategi yang diterapkan penyuluh dalam berbagai program. Berdasarkan latar belakang di atas, maka tujuan penelitian ini adalah mendeskripsikan persepsi penyuluh dalam pemanfatna teknologi digital dalam penyampaian penyuluhan.

\section{METODE PENELITIAN}

Penelitian ini didisain sebagai penelitian survei dengan pendekatan deskriptif kualitatif karena data yang terkumpul nantinya akan dianalisis secara kualitatif. Metode deskriptif kualitatif bertujuan untuk menggambarkan, meringkas berbagai kondisi, berbagai situasi atau berbagai fenomena realitas sosial yang ada di masyarakat yang menjadi objek penelitian, dan berupaya menarik realitas itu ke permukaan sebagai suatu ciri, karakter, sifat, model, tanda atau gambaran tentang kondisi, situasi ataupun fenomena tertentu (Bungin, 2017). Arikunto (2013) menyatakan bahwa metode deskriptif bertujuan untuk memahami makna dibalik data yang tampak. Populasi dalam penelitian ini adalah penyuluh pertanian yang bertugas di Kabupaten Tasikmalaya. Sampel diambil secara random sampling 
mengggunakan teknik sampling dengan menggunakan rumus slovin (1960) dari populasi 150 orang dengan kelonggaran sebesar 10 persen dan sampel berjumlah 60 orang. Data dikumpulkan dengan wawancara menggunakan kuesioner terstruktur. Data yang diperoleh dianalisis secara tabulasi dengan perhitungan skor dan dijelaskan secara deskriptif. Rumus yang digunakan untuk membuat interval kelas sebagai berikut:

$$
\begin{aligned}
& \text { NR }=\text { NST }- \text { NSR } \\
& \text { PI }=\text { NR }: \text { JIK } \\
& \text { Dimana: } \\
& \text { NR = Nilai Range } \\
& \text { NST = Nilai Skor Tertinggi } \\
& \text { NSR = Nilai Skor Terendah } \\
& \text { JIK }=\text { Jumlah Interval Kelas } \\
& \text { PI } \quad=\text { Panjang Interval }
\end{aligned}
$$

Berdasarkan perhitungan maka interval kelas untuk mengukur persepsi penyuluh terhadap strategi kominukasi dalam pemanfatan media informasi di era digital dapat dilihat pada Tabel 1.

Tabel 1 Nilai Interval Persepsi Petani Terhadap Strategi Komunikasi Penyuluh

\begin{tabular}{cccc}
\hline $\begin{array}{c}\text { Nilai interval } \\
\text { (skor total) }\end{array}$ & $\begin{array}{c}\text { Nilai Interval } \\
\text { (per indikator) }\end{array}$ & $\begin{array}{c}\text { Nilai Interval } \\
\text { (per pertanyaan }\end{array}$ & Kriteria \\
\hline $9,00 \leq \mathrm{x} \leq 18,00$ & $3,00 \leq \mathrm{x} \leq 5,00$ & $1,00 \leq \mathrm{x} \leq 1,67$ & Rendah \\
$8,00<\mathrm{x} \leq 27,00$ & $5,00<\mathrm{x} \leq 7,00$ & $1,67<\mathrm{x} \leq 2,34$ & Sedang \\
$27,00<\mathrm{x} \leq 36,00$ & $7,00<\mathrm{x} \leq 9,00$ & $2,34<\mathrm{x} \leq 3,00$ & Tinggi \\
\hline
\end{tabular}

\section{HASIL DAN PEMBAHASAN}

\section{Persepsi Penyuluh Terhadap Strategi Komunikasi dalam Pemanfatan Media Informasi di Era Digital}

Andriaty dkk (2011) menyatakan bahwa ketersediaan informasi teknologi di suatu wilayah akan berdampak terhadap tingkat pemenuhan kebutuhan informasi sehingga penyuluh bisa menyampakan informasi yang berkualitas kepada masyarakat. Pemanfaatan dari media teknologi informasi telah banyak dimanfaatkan oleh penyuluh pertanian Kabupaten Tasikmalaya dalam menunjang kegiatan penyuluhan yang ada. Dari hasil wawancara dengan penyuluh setempat kebanyakan dari mereka telah mencoba memanfaatkan media teknologi informasi yang mendukung seperti media internet maupun media cetak.

Untuk mengakses informasi seputar pertanian penyuluh pertanian Kabupaten Tasikmalaya lebih sering menggunakan media handphone dan laptop milik pribadi. Penyuluh pertanian lebih sering menggunakan laptop pribadi karena media ini memudahkan mereka untuk dapat menggunakan secara optimal karena tampilan informasinya menjadi lebih jelas. Ketika mereka sedang berada di lapangan, penyuluh akan mulai memanfaatkan smartphone atau handphone yang mereka miliki karena tuntutan untuk menemukan informasi 
yang penting secara cepat dan tepat. Hal tersebut sejalan dengan penelitian Sunarsi dan Dirgahayu (2015) yang menyatakan bahwa pola penggunaan handphone sesuai dengan latar belakang dan status responden, dimana penggunaan handphone dilakukan di rumah, tempat kerja maupun di sekolah. Untuk lebih jelasnya mengenai pemanfaatan dalam kegiatan penyuluhan berbasis teknologi informasi akan dijelaskan sebagai berikut:

\section{Teknik Komunikasi}

Teknik komunikasi merupakan cara penyampaian informasi kepada petani secara efektif sehingga mampu tepat mengenai sasaran. Teknik komunikasi dalam strategi komunikasi yang digunakan penyuluh dilihat dari cara penyampaian pesan, teknik penyampaian pesan dan penggunaan bahasa, secara rinci dapat dilihat pada Tabel 2 .

Tabel 2 Skor rata-rata teknik komunikasi penyuluh di Kabupaten Tasikmalaya

\begin{tabular}{|c|c|c|}
\hline Komponen Indikator & Skor & Kriteria \\
\hline Cara penyampaian pesan & 2,62 & Tinggi \\
\hline $\begin{array}{l}\text { Teknik penyampaian } \\
\text { pesan }\end{array}$ & 2,60 & Tinggi \\
\hline Penggunaan bahasa & 2,83 & Tinggi \\
\hline Jumlah & 8,05 & Tinggi \\
\hline
\end{tabular}

Komponen strategi komunikasi penyuluh dalam teknik komunikasi yang dilihat dari cara penyampaian pesan dengan skor rata-rata 2,62 berada pada kriteria tinggi. Hal ini menunjukkan penyuluh memiliki peran dalam penyapaian pesan kepada kelompok tani maupun individu dengan cara tatap muka, yaitu ketika sosialisasi yang diberikan oleh penyuluh kepada kelompok tani maupun masyarakat disampaikan secara formal dan non formal. Cara penyampaian pesan yang dilakukan oleh penyuluh berupa komunikasi yang bersifat informatif dan persuasif dengan cara mengajak, mengarahkan, serta membangun motivasi kelompok atau masyarakat. Dan pesan yang disampaikan juga harus didasarkan dan disesuaikan dengan permintaan serta kebutuhan kelompok tani atau masyarakat; oleh karena itu, maka pesan yang disampaikan oleh penyuluh harus sesaui dengn kondisi keadan di lapangan. Sejalan dengan pendapat Indraningsih dkk (2010) yang menyatakan bahwa materi penyuluhan yang dibutuhkan oleh petani harus didasarkan pada kesempatan, kemauan dan kemampuan petani. Selain itu, pesan penyuluhan pertanian yang disampaikan oleh penyuluh harus sesuai dengan kondisi dan keadaan lapang. Menurut Puspitasari (2009), hal tersebut dilakukan untuk memudahkan petani dalam mempelajari materi yang disampaikan. Hasil penelitian yang dilakukan oleh 
Rintjap (2015) menunjukan bahwa materi penyuluhan yang disampaikan harus sesuai dengan kebutuhan sasarannya. Menurut Van Den Ban \& Hawkins (1999), bahwa pada diskusi kelompok penyuluh dapat berinteraksi langsung dengan petani maupun sesama petani dimana penyuluhan dapat disesuaikan dengan kebutuhan dan tingkat pengetahuan petani.

Teknik penyampaian pesan mendapatkan skor rata-rata 2,60 dengan kriteria tinggi. Hal ini berarti bahwa penyuluh harus memiliki kemampuan dalam pengemasan pesan yang berkaitan erat dengan metode penyuluhan yang dipilih. Metode penyuluhan pertanian yaitu dengan cara/teknik penyampaian materi penyuluhan kepada kelompok tani atau masyarakat harus sesuai dengan tujuan yang akan dicapai. Penyampaian pesan penyuluhan pertanian yang sering dilakukan oleh penyuluh pertanian di lapangan karena adanya keterbatasan dana atau biaya. Penyuluh sering menggunakan satu atau dua metode penyuluhan yaitu ceramah dan diskusi dimana pesan dapat disampaikan. Teknik penyampaian yang dilakukan melalui penyuluhan yaitu ceramah dan terkadang langsung praktek berupa peragaan. Van Den Ban \& Hawkins (1999) menyatakan bahwa ceramah merupakan salah satu sarana penting untuk mengalihkan informasi dalam penyuluhan.

Kemudian untuk komponen penggunaan bahasa juga berada pada kriteria tinggi dengan skor rata-rata 2,83, artinya petani mengerti dan memahami bahasa yang digunakan penyuluh dalam menyampaikan pesan. Dalam hal ini, meskipun penyuluh bukan penduduk lokal, tetapi penyuluh dapat menggunakan dan mengerti bahasa lokal petani sehingga petani lebih mudah dalam menerima pesan. Oleh sebab itu, maka penggunaan bahasa juga dapat mempengaruhi jalannya komunikasi agar efektif, biasanya penyuluh menggunakan bahasa sehari-hari pada kelompok tani dan masyarakat yaitu bahasa daerah yang mudah dipahami; dan sebaliknya jika penyampaian materi yang bersifat formal, maka cara penyampaianya menggunakan bahasa Indonesia. Sejalan dengan pendapat Wibowo dkk (2018) yang menyatakan bahwa agar petani dan anggota gapoktan mudah mengerti terhadap pesan yang disampaikan oleh petugas penyuluh pertanian lapangan (PPL) maka hendaknya lebih dominan menggunakan bahasa daerah setempat. 


\section{Saluran komunikasi}

Media komunikasi merupakan saluran komunikasi yang dapat menyampaikan pesan berupa informasi yang diperlukan. Media komunikasi merupakan bagian penting dari komunikasi yang berlangsung, karena berhubungan erat dengan pesan-pesan yang disampaikan. Hasil penelitian yang telah dilakukan berkaitan dengan saluran komunikasi diantaranya yaitu melalui saluran atau media antar pribadi (interpersonal). Penilaian skor respon petani dalam saluran dalam strategi komunikasi yang dilakukan oleh penyuluh pertanian lapangan dapat dilihat dalam Tabel 3.

Tabel 3 Skor rata-rata saluran komunikasi di Kabupaten Tasikmalaya

\begin{tabular}{lcc}
\hline \multicolumn{1}{c}{ Komponen Indikator } & Skor & Kriteria \\
\hline Bentuk media komunikasi & 2,77 & Tinggi \\
$\begin{array}{l}\text { Pemanfaatan media } \\
\text { komunikasi }\end{array}$ & 2,83 & Tinggi \\
$\begin{array}{l}\text { Pemanfaatan sumber } \\
\text { informasi lainnya }\end{array}$ & 2,87 & Tinggi \\
\hline Jumlah & 8,47 & Tinggi \\
\hline
\end{tabular}

Komponen strategi komunikasi Penyuluh Pertanian Lapangan dalam saluran komunikasi yang dilihat dari bentuk media komunikasi berada pada skor rata-rata 2,77 dengan kriteria tinggi. Hal ini bentuk media komunikasi yang dilakukan oleh penyuluh yaitu dengan menggunakan media elektronik dan tatap muka secara langsung. Petani mendapatkan informasi kapan saja dan dimana saja seputar pertanian. Pada saat petani bertemu, baik di sawah maupun dimana saja, mereka dapat saling bertukar informasi. Saluran komunikasi langsung terjadi diantara petani dengan petani ataupun petani dengan penyuluh. Penyampaian materi secara langsung dapat diterima dan diaplikasikan oleh anggota kelompok tani dengan efektif dan efisien. Selain itu, penyampaian materi secara langsung juga agar tidak terjadi kesalahpahaman dalam berkomunikasi. Berbeda terbalik dengan pendapat Indah (2018) yang menyatakan bahwa pemanfaatan teknologi informasi oleh penyuluh masih rendah, lebih dari dua pertiga penyuluh jarang memanfaatkan teknologi informasi. Rendahnya penyuluh memanfaatkan teknologi informasi, mengindikasikan bahwa penyuluh dalam mencari informasi hanya bergantung pada ketersediaan informasi dari dinas terkait.

Untuk komponen dalam pemanfaatan media informasi berada pada skor rata-rata 2,83 dengan kriteria tinggi. Hal ini berarti penyuluh dalam merancang atau menyusun pesan yang akan disampaikan kepada petani memanfaatkan berbagai media mulai dari radio, koran dan internet. Selain itu, 
penyuluh sekali-sekali mengajak menonton cara petani di daerah lain dalam melakukan budidaya padi melalui video atau youtube. Untuk mempermudah komunikasi lainnya, penyuluh juga bisa membuat grup dengan memanfaatkan media facebook dan whatsapp. Jika petani mengalami kesulitan maka petani akan segera menghubungi petani lainnya. Ketua kelompok tani juga bisa menghubungi penyuluh dan menyampaikan permasalahan yang dihadapi agar mendapatkan solusi pemecahan masalah. Petani juga dapat bertanya langsung melalui whatsapp atau menelepon dengan penyuluh. Oleh karena itu, maka whatsapp merupakan media komunikasi yang berguna dan lebih efektif dalam melakukan kegiatan penyuluhan dan whatsapp merupakan media komunikasi dalam pertukaran informasi dari petani pada penyuluh ataupun sebaliknya. Hal tersebut menunjukkan bahwa sebagian besar penyuluh telah dapat memanfaatkan jaringan internet untuk keperluan menjalan tugas dan tanggung jawab sebagai penyuluh. Sejalan dengan hasil penelitian Andarwati dan Sankarto (2005) yang menyatakan bahwa internet juga dianggap sebagai perpustakaan canggih yang berteknologi tinggi yang sangat memungkinkan informasi diperoleh dengan mudah.

Kemudian untuk komponen pemanfaatan sumber informasi lainnya berada pada kriteria sedang dengan skor rata-rata 2,87 dengan kriteria tinggi. Hal ini memperlihatkan bahwa penyuluh memanfaatkan informasi pertanian yang diperoleh melalui media internet. Informasi yang diperoleh dapat dimanfaatkan sebagai bahan penyusunan rancangan programa penyuluhan, bahan penyusunan rencana kerja penyuluh pertanian, bahan penyusunan materi penyuluhan, dan lain sebagainya. Pemanfaatan informasi pada penelitian ini diukur berdasarkan penggunaan informasi yang disimpan untuk pribadi, dibagikan ke sesama penyuluh atau disebarkan ke petani. Dengan membantu percepatan arus informasi, yang diberikan oleh penyuluh cukup efektif dalam berkomunikasi yaitu dengan membangun kerjasama yang baik dengan menjadikan ketua ataupun pengurus kelompok tani sebagai perpajangan tangan dari penyuluh untuk dapat mentransfer ilmu, informasi, pengetahuan dan teknologi kepada anggota kelompoknya, baik secara langsung melalui kegiatan kunjungan atau tatap muka, dan dengan memanfaatkan teknologi informasi dan 
komunikasi melalui sms, telephone, whatsapp dan panggilan video agar petani dapat memperoleh informasi secara cepat. Sebagian besar penyuluh memiliki persepsi bahwa dengan penggunaan media internet memberikan mereka kemudahan untuk mengakses informasi. Namun, dengan adanya media internet untuk mengakses informasi, penyuluh juga merasa harus selektif ketika akan mengolah suatu informasi dan tidak secara serta merta langsung menerapkan informasi yang mereka peroleh.

\section{Pesan komunikasi}

Pengukuran strategi komunikasi dalam pesan komunikasi dapat dilihat dari komponen indikator kesesuaian pesan dengan kebutuhan petani dan jenis pesan, sehingga informasi yang diberikan oleh penyuluh kepada kelompok tani atau masyarakat mudah diterima dengan jelas. Tujuan komunikasi yang dibangun oleh penyuluh agar terjadinya umpan balik (feedback) antara penyuluh dan kelompok tani atau masyarakat sehingga penyuluh dapat menilai atau mengetahui apakah sudah saling terjadi pengertian tetang pesan komunikasi yang diberikan oleh penyuluh kepada kelompok tani atau masyarakat. Umpan balik (feedback) sangat bermanfaat pula bagi penyuluh untuk melakukan upaya-upaya perbaikan dalam proses komunikasi dapat tercapai secara efektif. Skor persepsi petani terhadap pesan komunikasi dalam aktivitas komunikasi dapat dilihat dalam Tabel 4.

Tabel 4 Skor rata-rata pesan komunikasi di Kabupaten Tasikmalaya

\begin{tabular}{lcc}
\hline \multicolumn{1}{c}{ Komponen Indikator } & Skor & Kriteria \\
\hline $\begin{array}{l}\text { Kesesuaian pesan dengan } \\
\text { kebutuhan petani }\end{array}$ & 2,42 & Tinggi \\
$\begin{array}{l}\text { Jenis pesan } \\
\text { Jumlah }\end{array}$ & 2,56 & Tinggi \\
\hline
\end{tabular}

Komponen pesan komunikasi yang dilihat dari kesesuaian pesan yang disampaikan dengan kebutuhan petani berada pada skor 2,42 dengan kriteria tinggi. Hal ini menunjukkan bahwa pesan yang disampaikan oleh penyuluh kepada petani dinilai mampu memberikan solusi atas permasalahan petani dalam berusahatani. Semua penyuluh memberikan informasi dapat dipahami oleh petani berupa pesan inovasi dan solusi permasalahan. Pengukuran pesan dapat dilihat dari kesesuaian materi dengan kebutuhan petani di lapangan. Penyuluh memberikan pesan informasi dan inovasi diberikan secara langsung melalaui tatap muka ataupun memanfaatkan teknologi informasi dan komunikasi melalui sms, telephone, whatsapp dan panggilan video agar kelompok tani atau petani memperoleh informasi secara tepat dan jelas. Sejalan dengan pendapat Oktarina et al. (2019), 
bahwa aplikasi teknologi informasi melalui sarana komputer maupun telepon seluler (handphone) dalam implementasi informasi dapat berfungsi untuk mempercepat proses pembelajaran masyarakat.

Untuk komponen jenis pesan yang disampaikan berada pada skor rata-rata 2,56 dengan kriteria tinggi. Artinya penyuluh menyampaikan jenis pesan kepada kelompok tani atau petani dapat diterima dengan mudah. Penyuluhan pertanian harus efektif mampu menyelenggarakan penyuluhan dengan metode yang sesuai dengan sasaran, waktu, tempat, obyek (materi) dan subyek (peserta). Teknologi digital yang terus berkembang, memberikan peluang seluas-luasnya bagi kita untuk dapat memanfaatkan baik mendapatkan informasi maupun menyebarluaskan informasi secara cepat dalam ruang tanpa batas. Fasilitas ini dapat dimanfaatkan bagi penyuluh dalam menjalankan peran dan fungsi penyuluh untuk menjadi media belajar dan membantu memecahkan permasalahan.

\section{Penggunaan Media Internet}

Teknologi juga memegang peranan penting dalam pengembangan pertanian. Salah satu contoh teknologi informasi komunikasi yaitu internet. Internet menyajikan informasi tanpa batas. Lewat internet sangat diharapkan dapat digunakan untuk mencari segala informasi yang dibutuhkan dan dapat pula digunakan oleh masyarakat desa untuk meningkatkan kesejahteraan perekonomian melalui korespondensi dengan orang lain atau perusahaan di berbagai penjuru dunia. Informasi terkini bisa didapat dan dikirimkan dengan cepat. Selama ini masalah yang dihadapi oleh masyarakat desa disebabkan kurangnya informasi yang baru dan tepat.

Tabel 5. Skor rata-rata penggunaan media internet

\begin{tabular}{lcc}
\hline \multicolumn{1}{c}{ Komponen Indikator } & Skor & Kriteria \\
\hline $\begin{array}{l}\text { Waktu untuk mengakses } \\
\text { internet }\end{array}$ & 2,62 & Tinggi \\
Media akses internet & 2,70 & Tinggi \\
\hline Jumlah & 5,32 & Tinggi \\
\hline
\end{tabular}

Waktu untuk mengakses internet 2,62 memiliki kategori tinggi, hal ini memperlihatkan bahwa mayoritas penyuluh memiliki ketertarikan terhadap penggunaan internet dan telah mengakses internet secara rutin dalam menyiapkan program ataupun informasi-informasi yang dibutuhkan oleh petani. Penyuluh menilai internet merupakan media digital yang menampilkan info-info pertanian yang terbaru. Oleh sebab itu, maka penyuluh memanfaatkan layanan internet seperti akses terhadap layanan youtube dan google untuk mencari informasi berkaitan dengan permasalahan yang 
dihadapi oleh petani. Dengan adanya media internet maka penyuluh memanfatkan media sosial seperti whatsapp dan facebook untuk sarana penyuluhan dan diskusi tentang masalah yang dihadapi oleh kelompok tani atau petani. Selaras dengan pendapat Nila dkk (2019) yang menyatakan bahwa penyuluhan berbasis teknologi dan informasi, banyak mengakses informasi melalui media internet dan media cetak dan setelah adanya kegiatan penyuluhan, sasaran penyuluhan banyak merasakan manfaat dari adanya teknologi informasi.

Media akses internet 2,70 memiliki kategori tinggi, sebagian besar penyuluh memiliki persepsi bahwa dengan penggunaan media internet memberikan kemudahan untuk mengakses informasi. Penyuluh berpendapat bahwa informasi yang didapat pada layanan internet telah sesuai dengan kebutuhan dan kualitas informasi yang didapat sudah sesuai dengan kebutuhan petani di lapangan. Beberapa keuntungan yang dirasakan oleh penyuluh dengan memanfaatkan fasilitas internet diantaranya adalah kegiatan penyuluhan dapat disampaikan kapan dan di mana saja, pemanfaatan teknologi informasi, dapat menggunakan sumber yang telah ada di internet untuk kemudian dibuat materi penyuluhan, dapat berhubungan secara real time menggunakan video conference atau video streaming, mempunyai kemampuan untuk mengintegrasikan bermacam unsur media teks, grafik, audio, dan video dalam pemberian penyuluhan kepada petani. Sejalan dengan pendapat Harahap (2016) yang menyatakan bahwa internet merupakan media pemasok informasi terbesar saat ini.

\section{KESIMPULAN}

Penyuluh memiliki persepsi positif terhadap strategi komunikasi dalam pemanfaatan informasi yang dilihat dari teknik komunikasi, saluran komunikasi, pesan komunikasi dan penggunaan internet. Persepsi penyuluh berada pada kriteria tinggi dimana penyuluh sangat baik dalam melakukan komunikasi, baik secara langsung maupun secara tidak langsung menggunakan media digital seperti sms, whatsapp dan telepon sebgai saran komunikasi penyuluh dan petani. Mayoritas penyuluh memiliki ketertarikan terhadap penggunaan internet dan telah mengakses internet secara rutin dalam menyiapkan program ataupun informasi-informasi yang dibutuhkan oleh petani. Penyuluh berpendapat bahwa informasi yang 
didapat pada layanan internet telah sesuai dengan kebutuhan dan kualitas informasi yang didapat sudah sesuai dengan kebutuhan petani di lapangan. kegiatan penyuluhan dapat disampaikan kapan dan di mana saja, pemanfaatan teknologi informasi, dapat menggunakan sumber yang telah ada di internet untuk kemudian dibuat materi penyuluhan, dapat berhubungan secara real time menggunakan video conference atau video streaming, mempunyai kemampuan untuk mengintegrasikan bermacam unsur media teks, grafik, audio, dan video dalam pemberian penyuluhan kepada petani.

\section{Daftar Pustaka}

Andarwati, S.R., Sankarto B.S. (2005). Pemenuhan Kepuasan Penggunaan Internet Oleh Peneliti Badan Litbang Pertanian di Bogor. Jurnal Perpustakaan Pertanian. 14(1): 1017.

Andriaty, Etty, Bambang S. Sankarto, dan Endang Setyorini. 2011. Kajian Kebutuhan Informasi Teknologi Pertanian di Beberapa Kabupaten di Jawa. Jurnal Perpustakaan Pertanian, 20(2): 54-61.

Asdar A, Rahmadanih R, Sulili A. 2018. Persepsi Petani terhadap Peran Penyuluh dalam Pengembangan Kelompok Tani di Desa Mattirotasi Kecamatan Maros Baru Kabupaten Maros.

Bungin, Burhan. 2017. Penelitian Kualitatif: Komunikasi, Ekonomi,
Kebijakan Publik dan Ilmu Sosial Lainnya. Jakarta (ID): Kencana.

Dewan Ketahanan Pangan. 2006. Kebijakan Umum Ketahanan Pangan 2006-2009. Jurnal Gizi dan Pangan, 1(1): 57-63.

Harahap, Abdul Rahman. 2016. Pemanfaatan Teknologi Informasi dan Komunikasi dalam PemenuhanInformasi bagi Rumah Tangga Usaha Pertanian di Kecamatan Halongonan Kabupaten Padang Lawas Utara. Jurnal Penelitian Komunikasi dan Pembangunan, 17(2): 77-88.

Indraningsih, Kurnia Suci. Basita G. Sugihen. Prabowo Tjitropranoto, dkk. 2010. Kinerja Penyuluh Dari Perspektif Petani dan Eksistensi Penyuluh Swadaya Sebagai Pendamping Penyuluh Pertanian. Analisis Kebijakan Pertanian, 8(4): 303-321.

Indah Listiana, 2018. Pengaruh Pemanfaatan Teknologi Informasi Terhadap Kapasitas Penyuluh di Provinsi Lampung. Disertasi. Sekolah Pascasarjana Institute Pertanian Bogor.

Nila Sylvi Ratnadila, Andin H. Taryoto, Ani Leilani. 2019. Pemanfaatan Media Teknologi Informasi dalam Penyelenggaraan Penyuluhan Perikanan (Kasus Penyuluh Perikanan Kabupaten Tabanan Provinsi Bali). Jurnal Penyuluhan Perikanan dan Kelautan, 13(2): 189-204.

Oktarina S, Hakim N, Zainal AG., 2019. Persepsi Petani terhadap Strategi Komunikasi Penyuluh dalam Pemanfaatan Media Informasi di Era Digital. Jurnal Komunikasi Pembangunan, 17(2): 216-226.

Puspitasari, Putri Febrianty. 2009. Efektivitas Penyuluhan Terhadap Perilaku Petani Kopi Di Desa Sidomulyo Kecamatan Silo 
Kabupaten Jember. Skripsi. Jurusan Sosial Ekonomi Pertanian. Fakultas Pertanian. Universitas Jember.

Rintjap, Anneke Katrin. 2015. Efektivitas Komunikasi Dalam Penerimaan Informasi Pada Kelompok Peternak Sapi Potong di Kecamatan Remboken Kabupaten Minahasa Sulawesi Utara. PROS SEM NAS MASY BIODIV INDON 1 (7): 1711-1714, Oktober. 2015. Jurusan Sosial Ekonomi, Fakultas Peternakan Universitas Sam Ratulangi

Suganda, Romi, Bambang Sahono, dan Endang Widi Winarni. 2013. "Pengelolaan Sarana Pembelajaran Bahasa Inggris (Studi Deskriptif Kualitatif di SMP Negeri 20 Bengkulu Selatan)." Universitas Bengkulu.

Sunarsi, Risa dan Dida Dirgahayu. 2015. "Pemanfaatan Handphone Pada Masyarakat Pedesaan Di Desa Sukataris Kabupaten Cianjur." Jurnal Penelitian Komunikasi dan Opini Publik 19(1):57-67.
Sumardjo, L.M. Baga, R.S.H. Mulyandari. 2010. Cyber Extension : Peluang dan Tantangan dalam Revitalisasi Penyuluhan Pertanian. IPB Press. Bogor.

Slovin, M.J., 1960. Sampling, Simon and Schuster Inc. New York.

Van Den Ban AW, HS Hawkins. 1999. Penyuluhan Pertanian. Kanisius. Yogyakarta.

Wibowo HS, N Sutjipta, IW Windia. 2018. Peranan Penyuluh Pertanian Lapangan (PPL) sebagai Fasilitator dalam Penggunaan Metode Belajar Pendidikan Orang Dewasa (Andragogi) (Kasus di Gapoktan Madani, Desa Sampalan Klod, Kecamatan Dawan, Kabupaten Klungkung, Provinsi Bali). EJurnal Agribisnis dan Agrowisata, Vol7(1):21-3. 